\title{
Ets- 1 is a critical regulator of Ang II-mediated vascular inflammation and remodeling
}

\author{
Yumei Zhan,1,2 Courtney Brown,1,2 Elizabeth Maynard,1,2 Aleksandra Anshelevich,1,2 \\ Weihua Ni, ${ }^{1,2}$ I-Cheng Ho, ${ }^{3}$ and Peter Oettgen ${ }^{1,2}$
}

${ }^{1}$ Division of Cardiology, Beth Israel Deaconess Medical Center, and 2 Department of Medicine and New England Baptist Bone and Joint Institute, Harvard Institutes of Medicine, Boston, Massachusetts, USA.

3Division of Rheumatology, Allergy, and Immunology, Brigham and Women's Hospital, Boston, Massachusetts, USA.

\begin{abstract}
Ang II is a central mediator of vascular inflammation and remodeling. The transcription factor Ets-1 is rapidly induced in vascular smooth muscle and endothelial cells of the mouse thoracic aorta in response to systemic Ang II infusion. Arterial wall thickening, perivascular fibrosis, and cardiac hypertrophy are significantly diminished in Ets $1^{-/-}$mice compared with control mice in response to Ang II. The induction of 2 known targets of Ets-1, cyclin-dependent kinase inhibitor $p 21^{C I P}$ and plasminogen activator inbibitor-1 (PAI-1), by Ang II is markedly blunted in the aorta of Ets $1^{-/}$mice compared with wild-type controls. Expression of $\mathrm{p}^{21} 1^{\mathrm{CIP}}$ in VSMCs leads to cellular hypertrophy, whereas expression of $\mathrm{p} 21^{\mathrm{CIP}}$ in endothelial cells is associated with cell cycle arrest, apoptosis, and endothelial dysfunction. PAI-1 promotes the development of perivascular fibrosis. We have identified monocyte chemoattractant protein-1 (MCP-1) as a novel target for Ets-1. Expression of MCP-1 is similarly reduced in $\mathrm{Ets}^{-/-}$mice compared with control mice in response to Ang II, which results in significantly diminished recruitment of $T$ cells and macrophages to the vessel wall. In summary, our results support a critical role for Ets-1 as a transcriptional mediator of vascular inflammation and remodeling in response to Ang II.
\end{abstract}

\section{Introduction}

Chronic inflammation in blood vessels is observed in hypertensive patients and animals (1). Ang II is a vasoactive peptide with a wide variety of cardiovascular effects. In the vessel wall, Ang II promotes inflammation by inducing the production of reactive oxygen species, inflammatory cytokines, and adhesion molecules. In particular, the chemokine monocyte chemoattractant protein-1 (MCP-1) is induced by Ang II and acts as a central mediator of the inflammatory response in hypertensive vascular disease (2-4). Ang II also promotes VSMC and cardiac hypertrophy (5).

Several transcription factors are involved in mediating the effects of Ang II in vascular smooth muscle and endothelial cells. Exposure of VSMCs to Ang II leads to a dose-dependent and rapid induction in the immediate early response genes encoding c-fos, c-jun, and early growth response 1 (Egr-1) (6-8). The signal transducers and activators of transcription STAT1 and STAT2 are also activated via tyrosine phosphorylation in response to Ang II (9). In addition to rapidly inducing immediate early response genes, Ang II

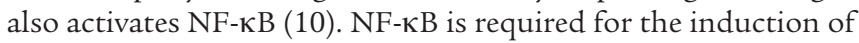
IL-6 in response to Ang II in VSMCs and adhesion molecules in endothelial cells $(11,12)$. Recently, a role for Krueppel-like zinc finger transcription factor 5 (KLF5) was identified. Targeted disruption of KLF5 leads to marked reductions in Ang II-mediated vascular remodeling and cardiac hypertrophy (13).

Nonstandard abbreviations used: ChIP, chromatin immunoprecipitation; HASMC human aortic SMC; KLF5, Krueppel-like zinc finger transcription factor 5; MCP-1, monocyte chemoattractant protein-1; PAI-1, plasminogen activator inhibitor-1; RASMC, rat aortic SMC

Conflict of interest: The authors have declared that no conflict of interest exists.

Citation for this article: J. Clin. Invest. 115:2508-2516 (2005).

doi:10.1172/JCI24403.
The Ets factors are a family of transcription factors that share a highly conserved DNA-binding domain and are involved in regulating a wide variety of biological processes (14). Ets- 1 is the prototypical member of this family and is expressed in endothelial cells and VSMCs. Ets-1 regulates the expression of genes involved in endothelial function and angiogenesis, including the VEGF receptors and Ang II, and the migration of cells such as matrix metalloproteinases and $\beta_{3}$ integrins (15-19). Dominant negative forms of Ets-1 exhibit antiangiogenic activity (20).

The role of Ets- 1 as a regulator of VSMC function has been less well studied. Ets- 1 is induced in VSMCs in response to a variety of stimuli including Ang II, PDGF-BB, and TNF- $\alpha$ (21-23). The purpose of this study was to further define the exact of role of Ets- 1 as a transcriptional mediator of Ang II in vivo. Ang II induces the expression of several genes involved in regulating inflammation, coagulation, and hypertrophy (24). In this study, we identified several downstream targets of Ang II, including MCP-1, plasminogen activator inhibitor-1 (PAI-1), and the cyclin-dependent kinase inhibitor $\mathrm{p} 21^{\mathrm{CIP}}$, that are dependent on Ets- 1 for induction by Ang II. Chronic administration of Ang II to Ets $1^{-/-}$compared with control mice was associated with a marked decrease in vascular remodeling, including reductions in vascular hypertrophy and perivascular fibrosis. The results of our study support a critical role for Ets-1 as a downstream transcriptional mediator of Ang II.

\section{Results}

Involvement of Ets-1 in Ang II-mediated vascular remodeling. Ang II has previously been shown to induce the expression of Ets- 1 in primary cultured VSMCs (21). For evaluation of the potential role of Ets-1 as a transcriptional mediator of Ang II effects in vivo, C57BL $/ 6$ mice were chronically infused with Ang II $(1.4 \mathrm{mg} / \mathrm{kg} / \mathrm{d})$ via an osmotic 

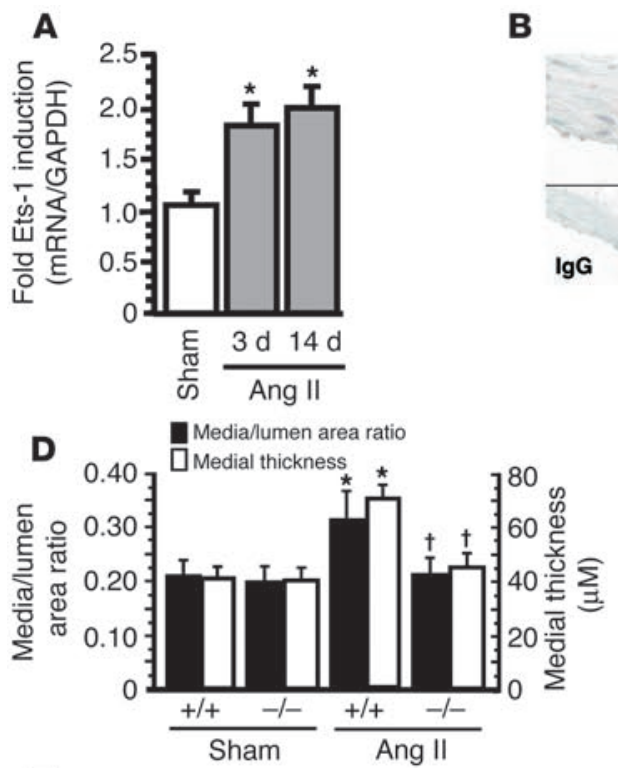

$\mathbf{E}$

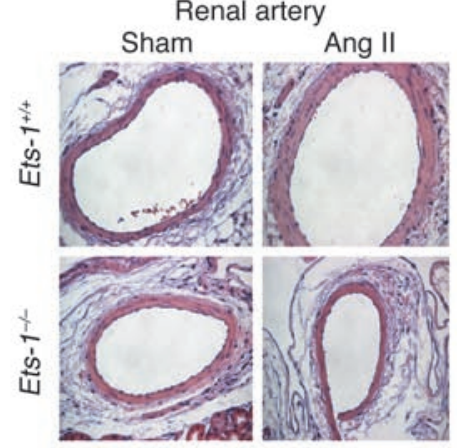

B

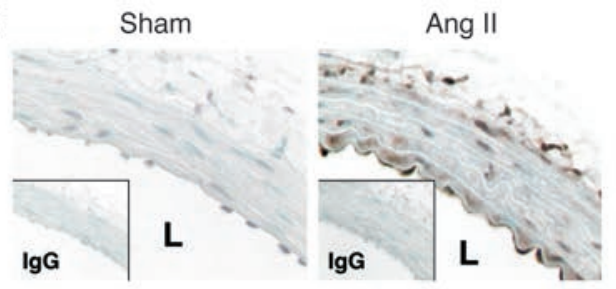

C Aorta
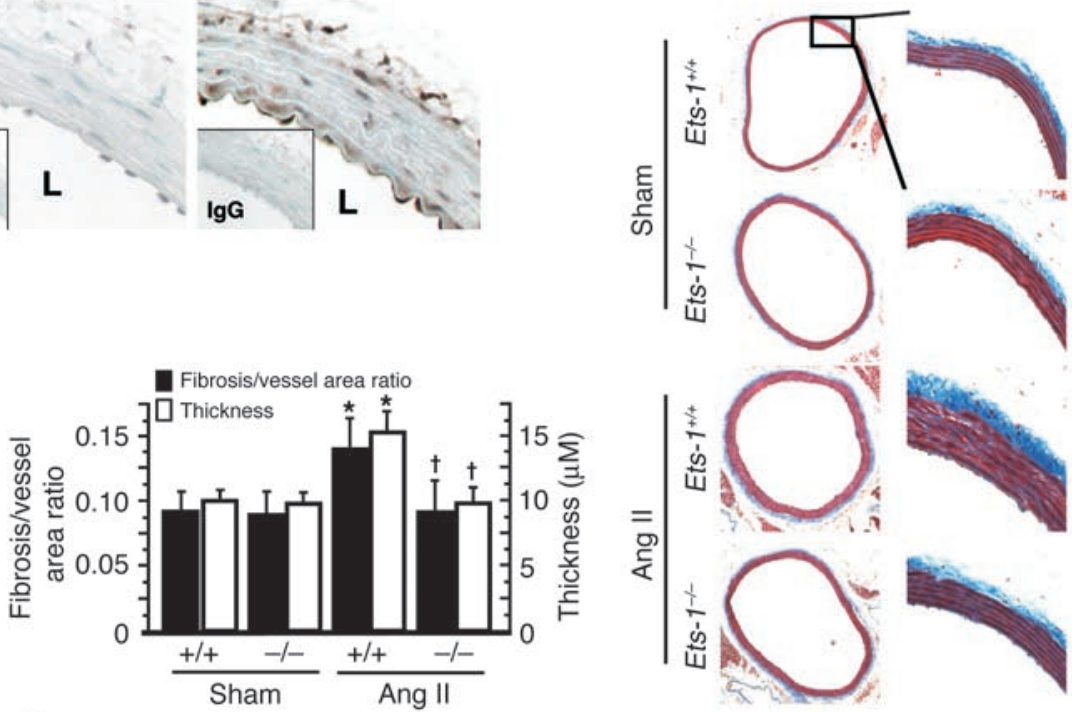

$\mathbf{F}$

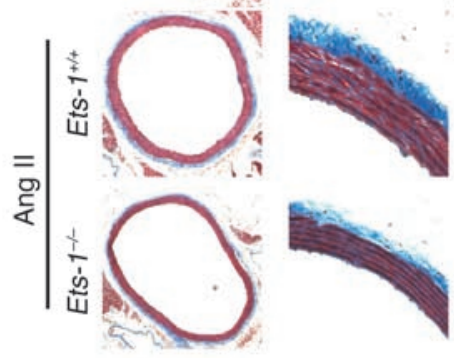

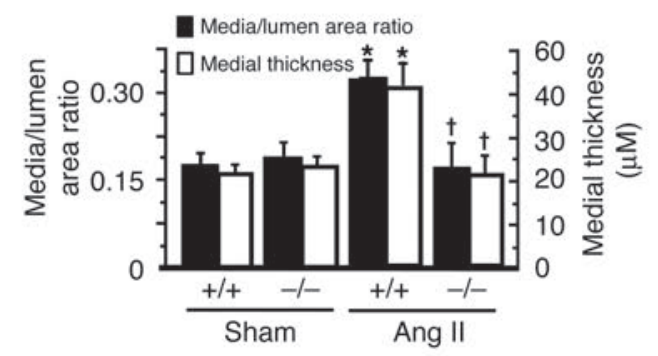

\section{Figure 1}

In vivo induction of Ets-1 in response to Ang II and altered vascular remodeling in Ets 1-/- mice. (A) Ets-1 expression as measured by quantitative RT-PCR in the thoracic aorta of C57BL/6 mice, 3 days and 2 weeks after Ang II infusion ( $1.4 \mathrm{mg} / \mathrm{kg} / \mathrm{d})$. Values are expressed as fold induction compared with sham-treated controls. (B) Immunohistochemical analysis of Ets-1 expression after infusion of Ang II for 2 weeks in C57BL/6 mice compared with sham-treated controls. L, lumen. Original magnification, $\times 200$. (C) Comparison of the effects of Ang II infusion and sham treatment on perivascular fibrosis and arterial thickening in the aorta of Ets $1^{+/+}$versus Ets $1^{-/-}$mice. Aortic sections were stained with Masson trichrome stain. Original magnification, $\times 20$ (left) and ×100 (right). (D) Analysis of medial thickness and medial area/lumen area ratio (left) and perivascular fibrosis thickness and fibrosis area/vessel area ratio (right) in Ets $1^{+/+}$versus Ets $1^{-1-}$ mice compared with sham-treated controls. (E) Comparison of the effect of Ang II infusion versus sham treatment on renal artery hypertrophy in Ets $1^{+/+}$versus Ets $1^{-/-}$mice. Sections were stained with H\&E. (F) Statistical analysis of medial thickness of the renal arteries in Ets $1^{+/+}$versus Ets $1^{-/-}$mice compared with sham-treated controls. ${ }^{*} P<0.01$ versus corresponding sham-treated control; ${ }^{\dagger} P<0.01$ versus corresponding Ets ${ }^{+/+}$mice that underwent Ang II infusion. Values represent mean $\pm \mathrm{SEM} ; n=5$.

minipump. Thoracic aortic tissue samples were isolated after 3 days and 2 weeks. Ets-1 expression was assessed by quantitative RT-PCR. Ets-1 expression was significantly increased in the aorta as a result of Ang II infusion (Figure 1A). To define the cellular localization of Ets-1 within the aorta after Ang II infusion, we examined expression of Ets-1 by immunohistochemistry (Figure 1B). Robust Ets-1 expression was observed in the aortic endothelial cells, VSMCs, and cells of the adventitia of Ang II-treated animals compared with sham-treated controls.

Chronic infusion of Ang II in animals leads to increases in systolic blood pressure and vascular remodeling, including medial hypertrophy and perivascular fibrosis, that are also observed in patients with renovascular hypertension. In order to determine whether Ets-1 is required as a downstream transcriptional mediator of Ang II, we evaluated the effect of chronic Ang II infusion in
Ets $1^{+/+}$and Ets $1^{-/-}$mice. Infusion of Ang II for 2 weeks resulted in increased medial thickness and perivascular fibrosis within the thoracic aorta of in Ets $1^{+/+}$mice. Significant blunting of these Ang II-mediated effects was observed in Ets $1^{-/-}$mice (Figure 1, $\mathrm{C}$ and D). Similar reductions in medial thickness and the ratio of the media to vessel lumen were observed after Ang II was infused in the renal arteries of Ets $1^{-/-}$mice compared with Ets $1^{+/+}$control mice (Figure 1, E and F).

Ang II is a known mediator of VSMC hypertrophy. To further define the role of Ets- 1 in mediating VSMC hypertrophy, we isolated primary SMCs from the aortas of $E t s 1^{1^{-/}}$mice and Ets $1^{+/+}$littermate controls. These cells were cultured in the presence of varying concentrations of Ang II, in the presence of $\left[{ }^{3} \mathrm{H}\right]$ leucine, in order to allow measurement of protein synthesis. A significant decrease in $\left[{ }^{3} \mathrm{H}\right]$ leucine uptake was observed in the Ets $1^{-/-}$mice compared 

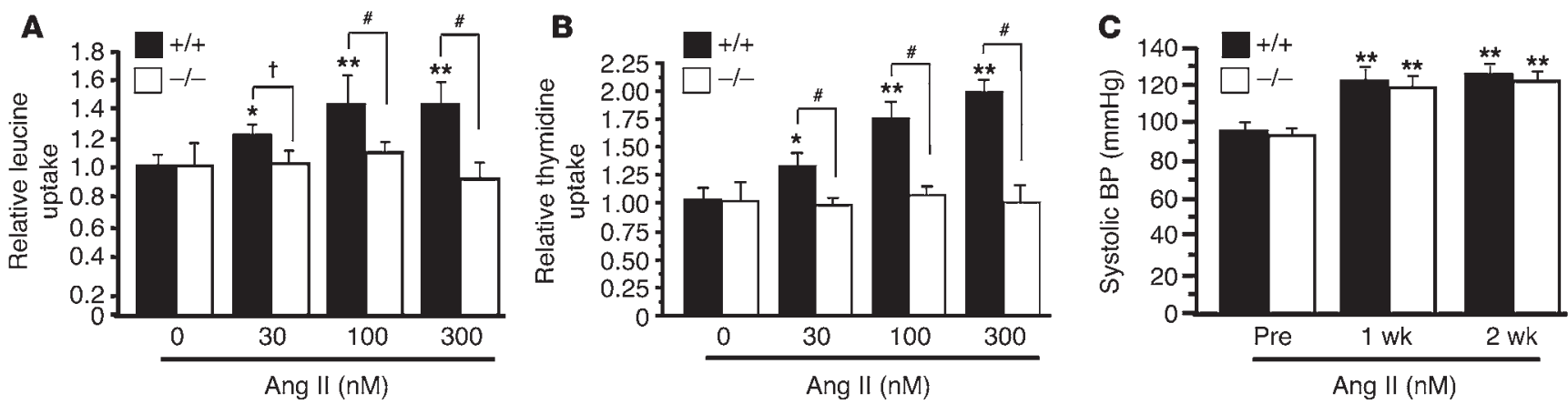

Figure 2

Effect of Ang II on systolic blood pressure and $\left[{ }^{3} \mathrm{H}\right]$ leucine and $\left[{ }^{3} \mathrm{H}\right]$ thymidine incorporation in cultured primary aortic SMCs isolated from Ets $1^{+/+}$ and Ets $1^{-1-}$ mice. (A) Quiescent aortic SMCs were cultured in the presence of varying concentrations of Ang II $(0,30,100$, and $300 \mathrm{nM})$ for 18 hours and pulsed with $\left[{ }^{3} \mathrm{H}\right]$ leucine for 6 hours. Incorporation was measured by a liquid scintillation spectrophotometer. Experiments were repeated 3 times. Values represent mean \pm SEM. ${ }^{*} P<0.05,{ }^{* *} P<0.01$ versus unstimulated control cells; ${ }^{\dagger} P<0.05$; $\# P<0.01$. (B) Effect of Ang II on $\left[{ }^{3} \mathrm{H}\right]$ thymidine uptake. Quiescent aortic SMCs were stimulated with different concentrations of Ang II for 18 hours and pulsed with $\left[{ }^{3} \mathrm{H}\right]$ thymidine for 5 hours. Incorporation of $\left[{ }^{3} \mathrm{H}\right]$ thymidine was measured by a liquid scintillation spectrophotometer. Experiments were repeated 3 times. Values represent mean \pm SEM. ${ }^{*} P<0.05,{ }^{* *} P<0.01$ versus unstimulated control cells; ${ }^{*} P<0.01$. (C) Blood pressure of mice was measured using a Visitech BP-2000 system (see Methods) before (Pre) and after Ang II infusion (1.4 mg/kg/d) for 1 week and 2 weeks. ${ }^{* *} P<0.01$ versus SMCs before Ang II infusion.

with controls (Figure 2A). Ang II may also promote VSMC proliferation. To evaluate whether Ets- 1 is also required for Ang II-mediated VSMC proliferation, we measured $\left[{ }^{3} \mathrm{H}\right]$ thymidine incorporation after Ang II stimulation in VSMCs isolated from $\mathrm{Ets}^{-/-}$and wild-type control mice. A significant reduction in $\left[{ }^{3} \mathrm{H}\right]$ thymidine incorporation was observed in the SMCs isolated from Ets 1-/- mice compared with those from wild-type control mice (Figure 2B). The blood pressure of the mice was evaluated at baseline and 3, 7, and 14 days after initiation of the Ang II infusion. There was no difference in the systolic blood pressure observed in Ets $1^{-/-}$compared with controls (Figure $2 \mathrm{C}$ ). These results suggest that the reductions in vascular remodeling observed in $\mathrm{Ets}^{\mathrm{I}^{--}}$mice are not dependent upon alterations in blood pressure but more likely are due to changes in the direct cellular effects of Ang II. Ang II has also been shown to be a potent stimulus for cardiac hypertrophy. We therefore evaluated the effect of chronic Ang II administration on cardiac hypertrophy. Ang II infusion resulted in a gradual but significant increase in heart size over 2 weeks compared with sham treatment (Supplemental Figure 1; available online with this article; doi:10.1172/JCI24403DS1). This effect was significantly diminished in Ets $1^{-/-}$mice.

Involvement of Ets-1 in Ang II-mediated vascular inflammation. Ang II exhibits significant proinflammatory action in the vessel wall by inducing the production of reactive oxygen species, inflammatory cytokines, and adhesion molecules that promote the recruitment of inflammatory cells (24). To evaluate changes in the infiltration of inflammatory cells into the arterial wall after Ang II infusion in $E t s 1^{+/+}$versus $E t s 1^{-/-}$mice, we determined the number of T cells

\section{Figure 3}

Reduction in the recruitment of inflammatory cells in Ets $1^{-/-}$mice in response to Ang II. Immunohistochemical staining (upper panels; original magnification, $\times 250)$ and quantitative analysis (lower panels) of infiltration of CD3 (T cells) and Mac3 (macrophages) in the thoracic aorta of $E t s 1^{+/+}$versus Ets $1^{-/-}$mice after infusion of Ang II $(1.4 \mathrm{mg} / \mathrm{kg} / \mathrm{d})$ for 1 week. Arrowheads indicate positively stained cells. ${ }^{*} P<0.01$ versus Ets ${ }^{+/+}$mice. Values represent mean \pm SEM; $n=5$.
(CD3) and macrophages (Mac3) by immunostaining of the aorta. A significant reduction in the quantity of cells of both types was observed after 1 week (Figure 3 ).

There are several potential mechanisms by which Ets- 1 could function as a transcriptional mediator of vascular remodeling. Ets-1 could promote the expression of genes involved in regulating VSMC growth or the expression of genes that promote the recruitment of inflammatory cells or induce the expression of genes that regulate the development of fibrosis. Known target genes for Ets- 1 that could play a role in mediating these responses include the cyclin-dependent kinase inhibitor $p 21^{C I P}$ and PAI-1. The expression of $\mathrm{p} 21^{\mathrm{CIP}}$ and PAI- 1 was evaluated by immunohistochemistry in Ets $1^{+/+}$versus $E t s 1^{1^{-/}}$mice. Both of these genes were markedly induced in the $E t s 1^{+/+}$mice in response to Ang II in vascular endothelial and SMCs. In contrast, minimal induction of these genes was observed in the Ets $1^{-/-}$mice after Ang II infusion (Figure 4) and in the sham-treated controls (data not
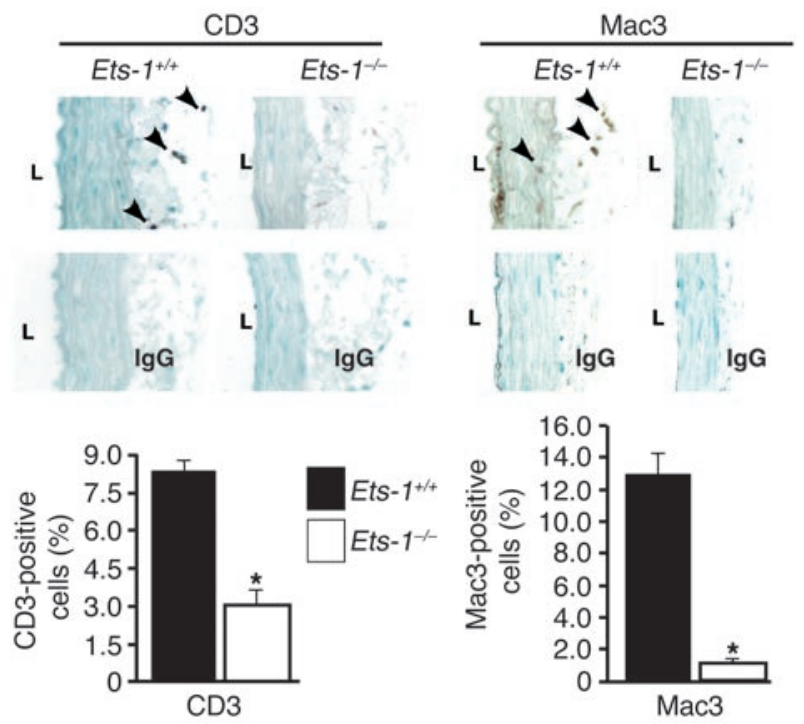

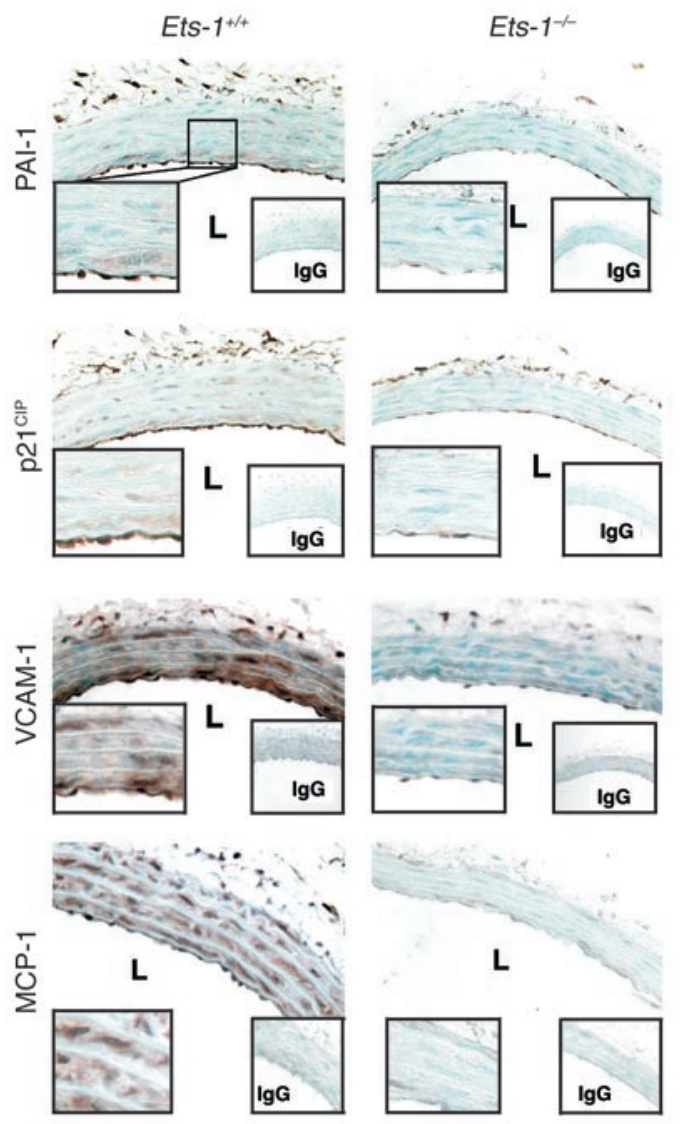

Figure 4

Immunohistochemical staining of PAI-1, p21 CIP, VCAM-1, and MCP-1 in the thoracic aorta of $E t s 1^{+/+}$and Ets $1^{-/-}$mice after Ang II infusion. Evaluation of expressions of PAI-1, cyclin-dependent kinase inhibitor p21 CIP, VCAM-1, and MCP-1 after 1 week of Ang II infusion (1.4 mg/kg/d) in the thoracic aorta of Ets $1^{+/+}$compared with Ets $1^{-/-}$mice. Isotypematched controls are shown below each panel. Original magnification, $\times 100$; enlarged regions, $\times 400$.

shown). In addition to known target genes, we were also interested in determining whether other genes that are known to be involved in mediating the inflammatory effects of Ang II are regulated by Ets-1. Systemic administration of Ang II has previously been shown to induce the expression of VCAM- 1 in the aorta of rats, in endothelial cells, and in aortic SMCs (25). We similarly observed robust VCAM-1 expression in the vascular endothelium and to a lesser degree in VSMCs in response to Ang II infusion. This induction was markedly diminished in the Ets $1^{-/-}$mice (Figure 4). One of the main mediators of Ang II is the chemokine MCP-1. MCP-1 promotes the recruitment of monocytes to sites of inflammation. Absence of MCP-1 is associated with a marked reduction in the development of atherosclerosis in animal models (26). We examined the expression of MCP-1 in Ets $1^{-/-}$and Ets $1^{+/+}$mice in response to Ang II infusion after 1 week. MCP-1 expression was markedly blunted in the Ets $1^{-/-}$mice compared with the control Ets $1^{+/+}$mice (Figure 4). In contrast, no change in the inducible expression of IL-6 or tissue plasminogen activator (tPA) was observed (Figure 5). Interestingly, the transcription factor KLF5, which has also recently shown to be an important transcriptional mediator of Ang II, was also highly expressed in both the Ets $1^{-/-}$ and $E t s 1^{+/+}$mice in response to Ang II stimulation (13). This suggests that KLF5 is either upstream of Ets-1 or induced independently of Ets-1 in response to Ang II.

Regulation of the MCP-1 gene by Ets-1. To our knowledge, a role for Ets-1 in the regulation of the MCP-1 gene has not previously been demonstrated. Analysis of the nucleotide sequence of the proximal human $M C P-1$ promoter revealed 11 putative Ets-1binding sites (Figure 6A). We therefore performed transactivation studies in rat aortic SMCs (RASMCs) with a panel of Ets factors including Ets-1, Ets-2, NERF1A, NERF2, and ELF-1. Of the panel of Ets factors tested, Ets-1 was the most potent transactivator of the MCP-1 promoter, leading to an 10-fold increase in luciferase activity compared with the empty expression vector (Figure 6B). A chromatin immunoprecipitation (ChIP) assay was performed to examine whether Ets-1 binds to specific Ets sites within the MCP-1 promoter in human aortic SMCs (HASMCs) stimulated with Ang II. For the ChIP assay, PCR primers flanking 4 regions within the $M C P-1$ promoter were designed (Figure $6 \mathrm{~A}$ ). Crosslinked protein/DNA complexes were immunoprecipitated from HASMCs cultured in the presence of Ang II for 2 and 4 hours, with a rabbit polyclonal antibody against Ets-1. PCR analysis revealed 2 regions (ChIP2 and ChIP4) corresponding to Ets site -402 and to sites $-2,003,-2,078$, and $-2,253$ (Figure 6A) that were immunoprecipitated by the Ets-1 antibody, whereas ChIP regions 1 and 3 were not (Figure 6C). Among the 4 Ets binding sites within ChIP regions 2 and 4, we identified 2 highaffinity $(-2,253$ and -402$)$ sites for binding to Ets-1 in HASMCs stimulated with Ang II using a gel mobility shift assay. Results of a representative gel mobility shift assay using an oligonucleotide probe encoding the Ets- 1 binding site located at $-2,253$ are shown (Figure 6D). While only weak binding of Ets- 1 to this site was observed in unstimulated cells (lane 1), there was a timedependent increase in Ets-1 binding, with maximal binding 4 hours after stimulation with Ang II and weaker residual binding at 16 hours. The specificity of the complex formed at 4 hours was verified by the fact that $10 \mathrm{ng}$ of an unlabeled (cold) oligonucleotide was able to potently compete with the labeled probe (lane 6). Furthermore, when a mutant oligonucleotide in which the core Ets motif was mutated was used as a competitor, no change in binding was observed (lane 7). A polyclonal antibody directed against Ets-1 completely inhibited complex formation (lane 8), whereas an isotype-matched control had no effect (lane 9). Three deletion constructs, A, B, and C (Figure 6, A and E), and mutations of Ets-1 binding sites located at -2,253 (M1) and at -402 (M2) were used to evaluate the relative importance of these Ets bindings and regions of the $M C P-1$ promoter with respect to the induction of the promoter by Ang II in RASMCs (Figure 6E). The deletion constructs support the importance of 2 regions, between $-2,363$ and -970 and between -417 and +176 , for induction by Ang II. Interestingly, these regions include the 2 high-affinity Ets-1-binding regions (ChIP2 and ChIP4) identified by ChIP analysis. Furthermore, the M1 site mutant led to a reduction in transactivation by Ang II from 4.7- to 2.7-fold; similarly for the M2 mutant and the double mutant (M1 + M2), which were reduced to 3.2- and 2.1-fold, respectively. Similar reductions with respect to Ets- 1 transactivation of the $M C P-1$ promoter were observed, with a maximal reduction from 10 -fold to 5.5-fold with M1 + M2, which demonstrates that these 2 Ets-1binding sites are functionally important for transactivation of the $M C P-1$ promoter by Ets-1 (Figure 6F). 

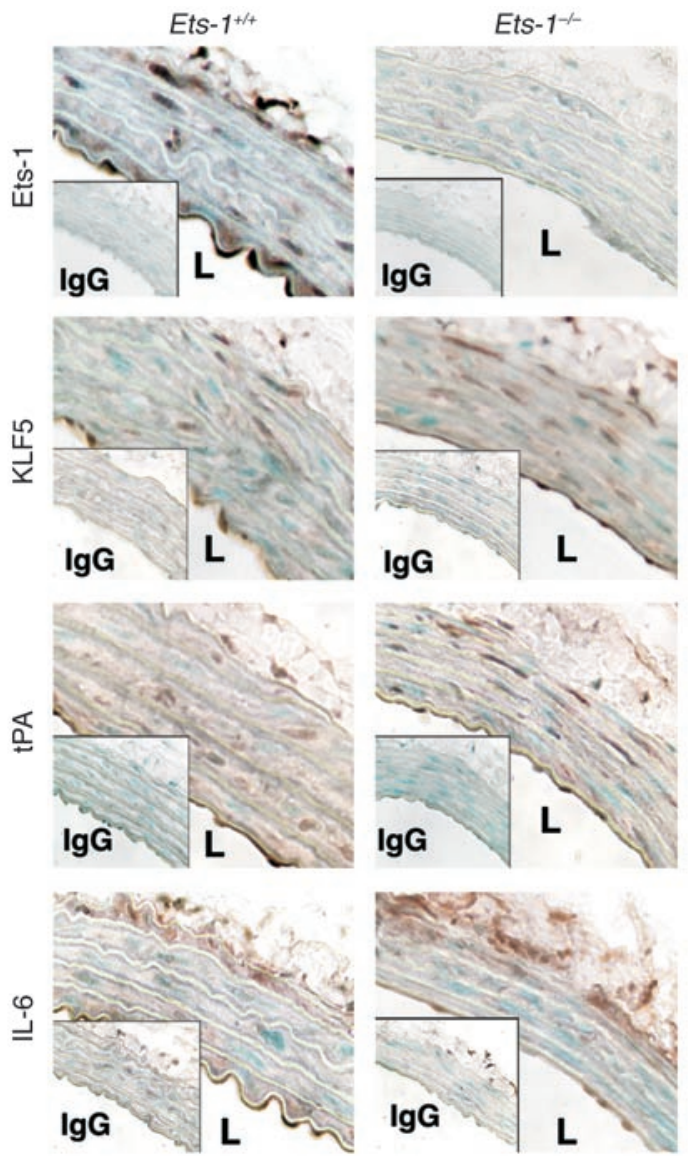

\section{Figure 5}

Immunohistochemical staining of KLF5, tissue plasminogen activator (tPA), and IL-6 in the thoracic aorta of Ets $1^{+/+}$and Ets $1^{-/-}$mice after infusion of Ang II (1.4 mg/kg/d) for 1 week. Original magnification, $\times 200$. Isotype-matched controls are shown below each panel.

\section{Discussion}

Vascular inflammation and remodeling accompany several diseases, including atherosclerosis, hypertension, and restenosis. Ang II is known to be a critical mediator of vascular inflammation. Direct infusion of Ang II into Apoe $e^{-/-}$mice leads to marked acceleration of atherosclerotic lesion development (27). Lesion formation is markedly attenuated by the administration of angiotensin-converting enzyme inhibitors. Vascular inflammation and remodeling are also observed in hypertensive patients. Ang II promotes the generation of reactive oxygen species, which stimulate the release of cytokines, growth factors, adhesion molecules, and chemokines. Chronic infusion of Ang II into normocholesterolemic animals is associated with significant vascular remodeling over the period of several weeks $(28,29)$. Prominent features of this remodeling process include medial hypertrophy, perivascular fibrosis, and infiltration of mononuclear cells. The results of our study support a critical role for Ets-1 as a transcriptional mediator of Ang II.

Although Ang II is a potent vasoactive peptide, several of its effects occur independently of changes in blood pressure. For example, local expression of the angiotensin-converting enzyme, through the use of viral vectors or through cardiac overexpression of angiotensinogen in transgenic animals, promotes the local production of Ang II, which leads to cardiac hypertrophy and fibrosis, without a significant change in blood pressure $(30,31)$. The development of cardiac hypertrophy in response to systemic administration of Ang II was inhibited in rats on a low-salt diet compared with those on a normal-salt diet, despite the fact that the blood pressure response to Ang II was similar in both groups (32). These results suggest that many of the cellular effects mediated by Ang II occur independently of the vasoactive effects. In the current study, we similarly observed significant reductions in inflammation, medial hypertrophy, perivascular fibrosis, and cardiac hypertrophy in $\mathrm{Ets}^{-/-}$versus wild-type littermate controls in response to Ang II infusion, despite the fact that the blood pressure in the 2 groups was the same.

Systemic administration of Ang II is associated with endothelial dysfunction and VSMC hypertrophy $(33,34)$. The cyclin-dependent kinase inhibitor $p 21^{C I P}$ is a known target gene of Ets-1 (35). We observed that $\mathrm{p} 21^{\mathrm{CIP}}$ was induced in response to Ang II in the wildtype mice but to a much lesser degree in the Ets $1^{-/-}$mice. The induction of $\mathrm{p} 21^{\mathrm{CIP}}$ by Ets- 1 is associated with differential effects on vascular endothelial and SMCs. In VSMCs, p $21^{\text {CIP }}$ promotes cell growth (35). Our results demonstrating a reduction in $\left[{ }^{3} \mathrm{H}\right]$ leucine and $\left[{ }^{3} \mathrm{H}\right]$ thymidine uptake in Ets $1^{-/-}$VSMCs, compared with control cells, in response to Ang II, further support a role for Ets-1 in mediating VSMC growth. In contrast, the upregulation of $\mathrm{p} 21^{\mathrm{CIP}}$ in endothelial cells is associated with cell cycle arrest or apoptosis (35-37). Overexpression of Ets- 1 in endothelial cells leads to increased expression of $\mathrm{p} 21^{\mathrm{CIP}}$ and apoptosis (38). These studies support a divergent role for $\mathrm{p} 21^{\mathrm{CIP}}$ in response to Ang II: promoting hypertrophy in VSMCs and dysfunction and cell death in endothelial cells.

The serine protease inhibitor PAI-1 is another known downstream target of Ets- 1 and is the primary physiological inhibitor of plasminogen activation. PAI- 1 is generated in SMCs and macrophages as well as endothelial cells. Whereas in plasma, PAI-1 acts as a critical determinant of the fibrinolytic system, in vascular tissue, it acts to modulate inflammatory responses by inhibiting cellular migration and matrix degradation (39-41). The generation of plasmin, which is inhibited by PAI-1, can activate latent MMPs that are involved in remodeling of the extracellular matrix $(42,43)$. PAI- 1 contributes to the development of fibrosis after chemical or ionizing radiation in the kidney and lung $(44,45)$. PAI- 1 has been shown to be critical for the perivascular fibrosis associated with animal models of hypertension (46). The mechanism by which this occurs is thought to involve an increase in collagen deposition and a reduction in MMP activity (47). Our study suggests that the induction of PAI- 1 in response to Ang II is dependent on Ets- 1 and that a reduction in PAI-1 may at least in part explain the diminished perivascular fibrosis observed in Ets $1^{-/-}$mice treated with Ang II.

MCP-1 is a central mediator of the inflammatory response in hypertensive vascular disease (48). Expression of MCP-1 is enhanced in the arterial walls of hypertensive animals (3). Inhibition of either MCP-1 or its receptor CCR2 prevents vascular inflammation in rats made hypertensive by chronic inhibition of nitric oxide (49-51). Ang II infusion was associated with significantly less macrophage accumulation and vascular hypertrophy in CCR2-deficient mice than in wild-type mice (51). We believe our study to be the first to demonstrate a critical role for Ets- 1 in the regulation of $M C P-1$ gene expression in VSMCs in response to Ang II. A critical component of Ang II-mediated vascular remodeling is the recruitment of inflammatory cells. Our findings demonstrate that in parallel with a reduction of MCP-1 expression there was an associated reduction in the recruitment of inflammatory cells to the arterial wall of the 
A
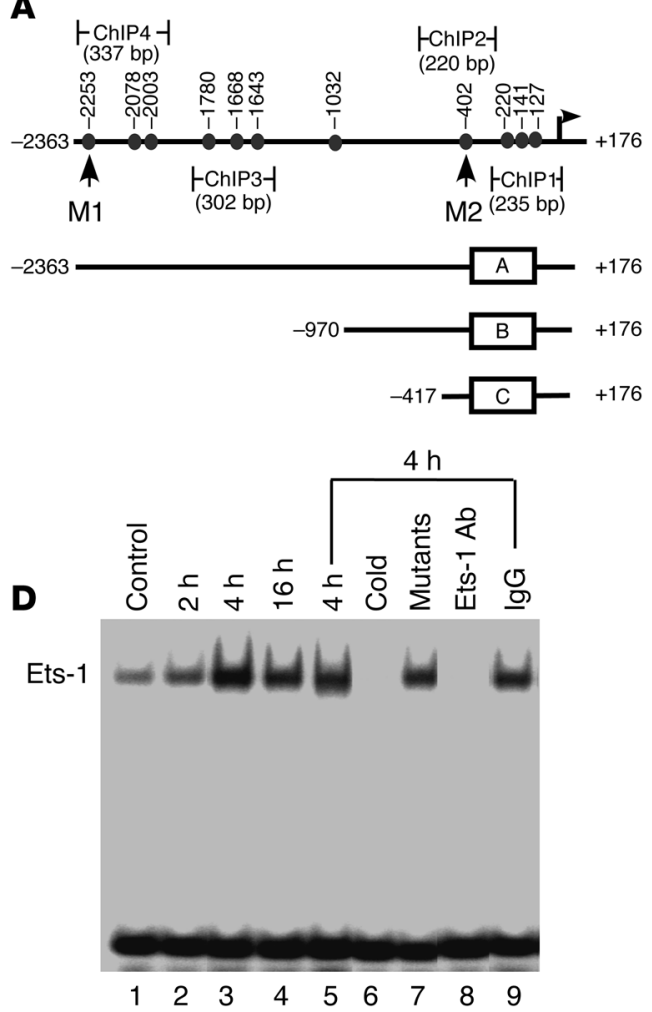
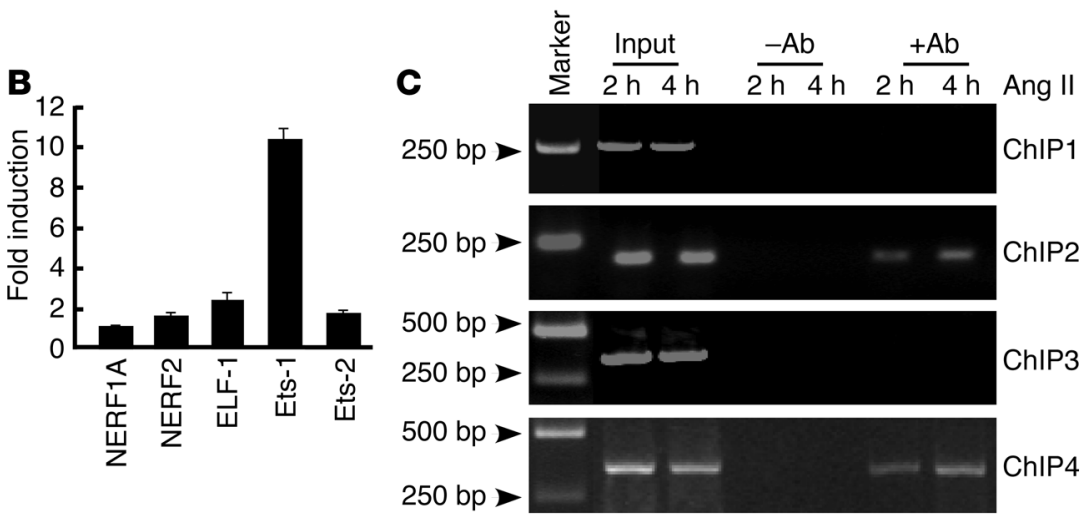

$\mathbf{E}$

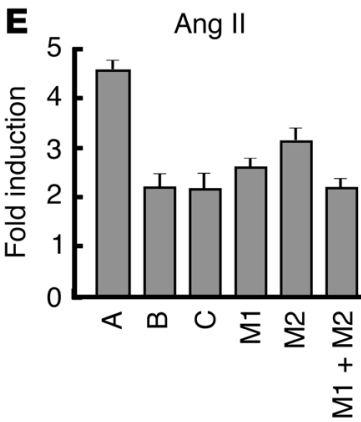

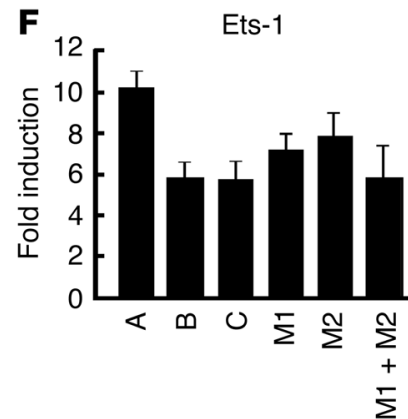

Figure 6

Regulation of the human MCP-1 gene by Ets-1. (A) Schematic of the human MCP-1 promoter with putative Ets-1 binding sites (filled circles). The transcription start site is indicated by the right arrow, and MCP-1 deletion constructs are designated A, B, and C. Regions used for PCR analysis in the ChIP assay (ChIP1-4) are shown with expected size of PCR fragments. Locations of Ets-1-binding site mutations are shown as M1 $(-2,253)$ and M2 (-402). (B) Transactivation of the MCP-1 promoter (construct A) by a panel of Ets factors in RASMCs shown as fold induction compared with control pCl expression plasmid. (C) ChIP assay of MCP-1 promoter using HASMCs after Ang II stimulation (100 nM) for 2 and 4 hours. An Ets-1 polyclonal antibody was used for precipitation. PCR analysis of the input (control), in the absence of antibody (-Ab), and after immunoprecipitation with antibody $(+\mathrm{Ab})$ using primers corresponding to 4 regions of the $M C P-1$ promoter. Molecular weight markers are shown on the left. (D) Gel mobility shift assay using oligonucleotide probe encoding the -2,253 MCP-1 promoter Ets-1 site. HASMCs were collected after stimulation with Ang II for 0 (Control), 2, 4, and 16 hours. The 4-hour lysate was incubated with the wild-type oligonucleotide probe, in the presence of either $10 \mathrm{ng}$ of unlabeled (Cold) wild-type or mutant oligonucleotide or $4 \mu \mathrm{g}$ of an Ets-1 polyclonal antibody or IgG isotype-matched control. (E) Ang II-induced (100 nM) transactivation of deletion constructs A, B, and C and site-directed mutants of the full-length MCP-1 promoter constructs containing the M1, M2, and M1 + M2 mutations in RASMCs are shown as fold induction compared with unstimulated control. (F) Transactivation of deletion constructs A, B, and C and site-directed mutants M1, M2, and M1 + M2 by Ets-1 in RASMCs are shown as fold induction compared with contransfection with empty mammalian expression plasmid.

mouse aorta. MCP-1 and CCR2 are also essential for the development and progression of atherosclerosis $(26,49,52,53)$.

Regulation of the MCP-1 gene in response to proinflammatory cytokines such as IL- $1 \beta$ and TNF- $\alpha$ is known to involve the transcription factors NF- $\mathrm{KB}$ and activator protein 1 (AP-1) in endothelial and VSMCs (54). In contrast, the induction of MCP-1 by Ang II in VSMCs does not appear to be dependent on NF-אB or AP-1 (55). Specific inhibitors of these transcription factors do not affect induction of MCP-1 by Ang II. In contrast, the transcription factor myocyte-specific enhancer-binding factor 2A (MEF2A) has recently been identified as a mediator of the induction of MCP-1 by Ang II (55). Mutations in the MEF2A gene have also been linked to coronary heart disease in a subset of patients (56). Our results also support a novel role for Ets- 1 as another transcriptional mediator of MCP-1 and suggest that, depending on the cell type and stimulus, the $M C P-1$ gene is differentially regulated.
In summary, the results of our study support a central role for Ets-1 as a transcriptional mediator of Ang II-mediated vascular inflammation and remodeling (Figure 7). We have identified several downstream effectors of Ang II, including P21 CIP , PAI-1, VCAM-1, and MCP-1, that are regulated by Ets-1. Future studies will be directed at identifying additional Ets- 1 target genes involved in inflammation and determining the role of Ets- 1 in other diseases associated with vascular inflammation.

\section{Methods}

Isolation and culture of the primary SMCs. Primary aortic SMCs were isolated from thoracic aortas of male $E t s 1^{+/+}$and $E t s 1^{1^{--}}$mice using collagenase, as previously described (57). Primary HASMCs were obtained from Cambrex Corp. Early-passage primary RASMCs were kindly provided by Mark Perrella (Brigham and Women's Hospital). For all experiments, primary cells from passages 3-7 were used. Cells were grown to 


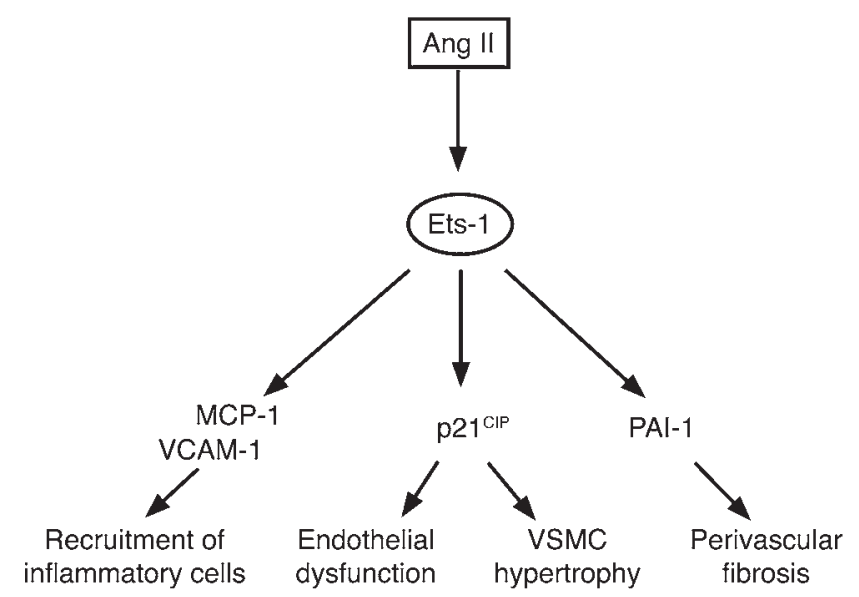

Figure 7

Schematic of Ang II-mediated effects via the Ets-1 transcription factor.

$70-80 \%$ confluence and then made quiescent by starvation for 24 hours before addition of Ang II.

Animals and Ang II infusion. Animals were housed in accordance with the guidelines of the American Association for Laboratory Animal Care. Animal research protocols were approved by the institutional animal care and use committees of the Beth Israel Deaconess Medical Center. The Ets $1^{-/-}$mice were generated by injection of Ets-1-deficient 129/Sv ES cells into C57BL/6 blastocysts to generate chimeras, and heterozygous males were bred with C57BL/ 6 females as previously described $(58,59)$. The mice were further backcrossed a total of 6 times onto a C57BL/ 6 background prior to initiation of the experiments with Ang II. Genotyping was performed by PCR of genomic DNA isolated from mouse tails. PCR was carried out as described below. All experiments were performed using male Ets $1^{-/-}$mice with littermate $E t s 1^{+/+}$controls. At least 5 pairs were prepared for every experiment. Mice were anesthetized by intraperitoneal injection of xylazine $(5 \mathrm{mg} / \mathrm{kg})$ and ketamine $(80 \mathrm{mg} / \mathrm{kg}$ ). The ALZET minipump (models 1007D and 1002; DURECT) containing 1.4 mg/kg/d Ang II (A-9525; Sigma-Aldrich) dissolved in saline or saline alone (sham treatment) was implanted subcutaneously. After the animals were euthanized, the thorax was opened, a 21gauge needle was placed into the left ventricle, and the inferior vena cava was severed. The animals were perfused with normal saline until the perfusate cleared and then with $4 \%$ paraformaldehyde at $100 \mathrm{mmHg}$.

Morphometric analysis. Tissues were paraffin embedded and cut into $5-\mu \mathrm{M}$ sections. Sections were stained with Masson trichrome stain to permit detection of perivascular fibrosis. Medial thickening and perivascular fibrosis were assessed as previously described $(49,60,61)$. In brief, the ratio of cross-sectional medial area to luminal area was used as the index of arterial thickening. The absolute medial thickness was also measured. Perivascular fibrosis was determined by calculating the ratio of the area of fibrosis surrounding the vessel, as measured by the area of blue staining (collagen deposition stained with aniline blue) immediately around the vessel, to total vessel area. The thickness of the fibrotic area surrounding the vessel was also measured. Measurements were performed using image-analyzing software (NIH Image, version 1.62; http://rsb.info.nih.gov/nih-image/). Three independent sections per artery of 5 Ets-1-deficient mice and their littermate controls were evaluated for each measurement.

Immunohistochemistry. Sections $(5 \mu \mathrm{M})$ cut from paraffin-embedded aorta, heart, or tissues were used for immunohistochemical staining. Sections were deparaffinized and rehydrated, and this was followed by microwave retrieval in $10 \mathrm{mM}$ Tris EDTA ( $\mathrm{pH} 7.5)$ at $93^{\circ} \mathrm{C}$ for 5 minutes. Three independent sections per artery of 5 pairs of mice $\left(E t s 1^{+/+}\right.$and $\left.E t s 1^{-/-}\right)$were examined. The primary antibodies used in the study were as follows: rabbit anti-human Ets-1 (N-276) (1:500; sc-111, Santa Cruz Biotechnology Inc.), rabbit anti-human PAI-1 (1:2,000; sc-8979, Santa Cruz Biotechnology Inc.), rabbit anti-human p21 CIP (1:2,000; sc-12902, Santa Cruz Biotechnology Inc.), goat anti-rat MCP-1 (1:1,000; sc-1785, Santa Cruz Biotechnology Inc.), rabbit anti-human CD3 (code A 0452; DakoCytomation), rabbit IgG fraction as negative control for CD3 (code X 0936; DakoCytomation), rat anti-mouse Mac3 (1:10; catalog 550292, BD Biosciences - Pharmingen), rat $\operatorname{IgG}_{1}$ as negative control for Mac3 (catalog 559072; BD Biosciences Pharmingen), rabbit anti-mouse KLF5 (1:1,000; PAB-11411, Orbigen Inc.), rabbit anti-human VCAM-1 (1:500; sc-8304, Santa Cruz Biotechnology Inc.), goat anti-mouse IL-6 (1:500; sc-1265, Santa Cruz Biotechnology Inc.), rabbit anti-human tPA (1:500; sc-15346, Santa Cruz Biotechnology Inc.), normal goat IgG as negative control for goat antibody (sc-2028; Santa Cruz Biotechnology Inc.), normal rabbit IgG as negative control for rabbit antibody (sc-2027; Santa Cruz Biotechnology Inc.). VECTASTAIN Elite ABC kits (PK-6105 goat IgG and PK-6101 rabbit IgG; Vector Laboratories) were used for the immunohistochemical staining. The sections were counterstained with methyl green (S1962; DakoCytomation). CD3-positive leukocytes and Mac3-positive macrophages in 3 independent sections per artery of 5 pairs of mice were counted. The number of cells that stained positive was expressed as percentage of the total number of cells.

Blood pressure measurement. The BP-2000 Blood Pressure Analysis System (Visitech Systems Inc.) was used to measure the blood pressure of the mice under conditions as recommended by the manufacturer. To train mice, we performed daily blood pressure measurements for 1 week prior to beginning experiments. Mice were placed in the machine at $37^{\circ} \mathrm{C}$ for 10 minutes and allowed to equilibrate prior to blood pressure measurement. Blood pressure was measured $0,3,7$, and 14 days after angiotensin infusion. Mice were weighed at ages 21 days and 8 weeks and at the time of each blood pressure measurement.

RNA isolation, quantitative RT-PCR, and genotyping. RNA from aorta of C57BL/6 mice was homogenized using Tissue-Tearor (model 985370; BioSpec Products Inc.) and isolated using an RNeasy Mini Kit (QIAGEN) with RNase-Free DNase Set (QIAGEN) to remove the genomic DNA. RNA was reverse transcribed to cDNA using oligo-dT primer and SuperScript II RT polymerase (Invitrogen Corp.). Real-time quantitative PCR was performed using the ABI PRISM 7700 sequence detector (TaqMan; Applied Biosystems) in combination with SYBR Green dye (Invitrogen Corp.). Ets-1 expression was analyzed using GAPDH as an internal control. An initial denaturation step was performed for 10 minutes at $95^{\circ} \mathrm{C}$ followed by an amplification for 40 cycles using the followng conditions for each cycle: 30 seconds at $95^{\circ} \mathrm{C}$, 30 seconds at $58^{\circ} \mathrm{C}$, and 1 minute at $72^{\circ} \mathrm{C}$. The following primers were

\section{Table 1}

Oligonucleotide sequence of primers used for chromatin immunoprecipitation

\begin{tabular}{|c|c|c|c|}
\hline Primers & Region ${ }^{A}$ & $\mathrm{Tm}$ & Size \\
\hline $\begin{array}{l}\text { CGCTTCACAGAAAGCAGAAT, } \\
\text { AGGAGGGATCTTCCATGAGT }\end{array}$ & ChIP1 & $58^{\circ} \mathrm{C}$ & $234 \mathrm{bp}$ \\
\hline $\begin{array}{l}\text { TCCTACAGTTCTGCTAGGCTTC, } \\
\text { CTTTCTGTGAAGCGAAAACTG } \\
\text { TGAGATTCAGGCAGAACAGA, }\end{array}$ & ChIP2 & $58^{\circ} \mathrm{C}$ & 220 \\
\hline $\begin{array}{l}\text { AACCCAGCTTTCGTTAGGTTA } \\
\text { ATTGGTCTCCTTCTCTGGAT, }\end{array}$ & ChIP3 & $58^{\circ} \mathrm{C}$ & 302 \\
\hline CTGTGCAACTTTGTGTAGGA & ChIP4 & $58^{\circ} \mathrm{C}$ & $337 \mathrm{bp}$ \\
\hline
\end{tabular}

AAs shown in Figure 6A. Tm, melting temperature. 
used: Ets-1, 5'-AGTGGACAGAAACCCATGTT(forward), 5'-CAAAGTCTGGGGCCAGCT (reverse); GAPDH, 5'-CAAAGTTGTCATGGATGACC (forward), 5'-CCATGGAGAAGGCTGGGG (reverse). The sequence of the primers used for phenotyping of $E t s 1^{+/+}$and $E t s 1^{1^{-/}}$mice was as follows: $5^{\prime}$ ATTGAACAAGATGGATTGCAC-3' (NeoA); 5'-TTCGTCCAGATCATCCTGATCGAC-3' (NeoB); 5'-GCTAGATGAGGGAGGAAG-3' (EtsF); and 5'CCAACAAAGTCTGGAGCC-3' (EtsR). RT-PCR was performed for 30 cycles under the following conditions for each cycle: 1 minute at $94^{\circ} \mathrm{C}, 1$ minute at $55^{\circ} \mathrm{C}$, and 1 minute at $72^{\circ} \mathrm{C}$ followed by 7 minutes at $72^{\circ} \mathrm{C}$. Five microliters of the amplification product was analyzed on a $2 \%$ agarose gel.

Measurements of protein synthesis. For measurement of the protein synthesis, cultured SMCs in 12-well plates were stimulated by Ang II for 18 hours and pulsed with $1 \mu \mathrm{Ci} /$ well $\left[{ }^{3} \mathrm{H}\right]$ leucine for 6 hours. Then cells were washed twice with iced PBS, incubated for 5 minutes in 10\% trichloroacetic acid on ice, washed with $99 \%$ ethanol, and dissolved in $0.5 \mathrm{~N} \mathrm{NaOH}$. The incorporation of $\left[{ }^{3} \mathrm{H}\right]$ leucine into trichloroacetic acid-insoluble material was measured by a liquid scintillation spectrophotometer.

Measurement of DNA synthesis. SMCs in 6-well plates were stimulated by Ang II for 18 hours and pulsed with $1 \mu \mathrm{Ci} / \mathrm{ml}\left[{ }^{3} \mathrm{H}\right]$ thymidine for 5 hours. Then cells were washed twice with PBS, incubated for 5 minutes in $5 \%$ trichloroacetic acid, washed with methanol, and dissolved in 99\% formic acid. The incorporation of $\left[{ }^{3} \mathrm{H}\right]$ thymidine into trichloroacetic acid-insoluble material was measured by a liquid scintillation spectrophotometer.

Expression vector and luciferase reporter gene constructs. A 2,539-bp fragment corresponding to nucleotides $-2,363$ to +176 of the human MCP-1 promoter was cloned from human genomic DNA by PCR and subcloned into the pGL2 luciferase reporter vector (Promega). The 2,539-bp fragment was inserted into the Kpn-HindIII site upstream of the luciferase gene of the pGL2 vector. Complementary DNA sequences encoding a panel of Ets factors were subcloned into the $\mathrm{pCI}$ (Promega) mammalian expression vector.

DNA transfection assays. Cotransfection of $2 \times 10^{5}$ RASMCs was carried out with $0.3 \mu \mathrm{g}$ of reporter gene construct DNA and $0.15 \mu \mathrm{g}$ of expression vector DNA using $4 \mu \mathrm{l}$ Lipofectamine (Invitrogen Corp.) as described previously (62). The cells were harvested 16 hours after transfection and assayed for luciferase activity. Transfections for each construct were performed independently in duplicate. Cotransfection of a second plasmid for determination of transfection efficiency was omitted because potential artifacts with this technique have been reported and because many commonly used viral promoters contain potential binding sites for Ets factors (63).

Site-directed mutagenesis. Site-directed mutagenesis of the MCP-1 promoter was performed using the QuickChange Site-Directed Mutagenesis Kit (Stratagene) according to the manufacturer's instructions. PCR was performed with Pfu Turbo Polymerase (Stratagene) using the wild-type $(-2,363$ to +176) MCP-1 promoter luciferase reporter construct as a template. The PCR primer encoding the MCP-1 promoter for the mutated Ets site at $-2,253$ with the GGAT core mutated to CTAT was 5 '-CATGCCACACTATGTCTATA- $3^{\prime}$ and for the Ets site at -402 with the TTCC mutated to TATC was $5^{\prime}$-AGAGCTCCTATCTGGCTGGGAGGC-3'. The PCR reaction was digested with $D p n I$, and the undigested plasmids were transformed into $\mathrm{DH} 5 \alpha$ bacteria. Individual minipreps were sequenced to verify incorporation of the Ets site mutations. A -402 mutant $M C P-1$ promoter construct was used as a template to generate a double $-2253,-402$ mutant.

ChIP analysis. ChIP analysis was performed using the Chip Assay Kit (Upstate), according to the manufacturer's instructions with minor modifications. Briefly, a total of $1 \times 10^{6}$ cells was crosslinked with $1 \%$ formaldehyde for 10 minutes at room temperature before being washed twice with ice-cold PBS containing protease inhibitors $(1 \mathrm{mM}$ phenylmethylsulfonyl fluoride, $1 \mu \mathrm{g} / \mathrm{ml}$ pepstain A, and $1 \mu \mathrm{g} / \mathrm{ml}$ aprotinin). After cells were scraped into a conical tube and centrifuged at $268 \mathrm{~g}$ at $4^{\circ} \mathrm{C}$ for 4 minutes, cell pellets were resuspended in $200 \mu \mathrm{l}$ of SDS lysis buffer and incubated on ice for 10 minutes. The lysates were sonicated to shear the DNA to lengths between 500 and 750 bp (confirmed by PCR) using a 550 Sonic Dismembrator (Fisher Scientific) according to the manufacturer's instructions. For immunoprecipitation, the lysates were incubated with an Ets-1 polyclonal antibody (Santa Cruz Biotechnology Inc.) at $4{ }^{\circ} \mathrm{C}$ overnight. Following immunoprecipitation, beads were washed once with low-salt immune complex wash buffer, once with high-salt immune complex wash buffer, once with $\mathrm{LiCl}$ immune complex wash buffer, and twice with Tris-EDTA buffer. We separated the histone-DNA complexes from the antibody by adding $250 \mu \mathrm{l}$ fresh elution buffer ( $\left.1 \% \mathrm{SDS}, 0.1 \mathrm{M} \mathrm{NaHCO}_{3}\right)$ and incubating the beads at room temperature for 15 minutes with rotation. After centrifugation, the supernatant was collected. Crosslinked histone-DNA complexes were separated by adding $20 \mu \mathrm{l}$ of $5 \mathrm{M} \mathrm{NaCl}$ and heating at $65^{\circ} \mathrm{C}$ for 4 hours. DNA was recovered using the MinElute PCR Purification Kit (catalog 28004; QIAGEN). The primers corresponding to 4 regions in the human MCP-1 promoter shown in Table 1 were used for PCR.

Gel mobility shift assays. For determination of DNA-protein interactions, EMSA was performed as previously described in detail (64). The sequences for the oligonucleotides corresponding to the Ets-1-binding site in the $M C P-1$ promoter were: GTCATGCCACAGGATGTCTA (-2253MCP-1), and GTCATGCCACAGGCTGTCTA (mutant-2253MCP-1).

Statistical analysis. The data are presented as mean \pm SEM. The statistical significance of differences was analyzed by ANOVA with a subsequent Dunnett test.

\section{Acknowledgments}

This work was supported by NIH grants HL-67219 (to P. Oettgen) and P01 HL76540-01 (to P. Oettgen).

Received for publication January 5, 2005, and accepted in revised form June 14, 2005.

Address correspondence to: Peter Oettgen, Harvard Institutes of Medicine, 4 Blackfan Circle, Boston, Massachusetts 02115, USA. Phone: (617) 667-3390; Fax: (617) 975-5299; E-mail: joettgen@ caregroup.harvard.edu.
1. Dzau, V.J., et al. 2001. The relevance of tissue angiotensin-converting enzyme: manifestations in mechanistic and endpoint data [review]. Am. J. Cardiol. 88:1L-20L.

2. Chen, X.L., Tummala, P.E., Olbrych, M.T., Alexander, R.W., and Medford, R.M. 1998. Angiotensin II induces monocyte chemoattractant protein-1 gene expression in rat vascular smooth muscle cells. Circ. Res. 83:952-959.

3. Capers, Q.T., et al. 1997. Monocyte chemoattractant protein-1 expression in aortic tissues of hypertensive rats. Hypertension. 30:1397-1402.

4. Usui, M., et al. 2000. Important role of local angiotensin II activity mediated via type 1 receptor in the pathogenesis of cardiovascular inflammatory changes induced by chronic blockade of nitric oxide synthesis in rats. Circulation. 101:305-310.

5. Berry, C., Touyz, R., Dominiczak, A.F., Webb, R.C., and Johns, D.G. 2001. Angiotensin receptors: signaling, vascular pathophysiology, and interactions with ceramide [review]. Am. J. Physiol. Heart Circ. Physiol. 281:H2337-H2365.

6. Naftilan, A.J., Pratt, R.E., Eldridge, C.S., Lin, H.L., and Dzau, V.J. 1989. Angiotensin II induces c-fos expression in smooth muscle via transcriptional control. Hypertension. 13:706-711.

7. Sachinidis, A., et al. 1992. Angiotensin II induces formation of the early growth response gene- 1 pro- tein in rat vascular smooth muscle cells. FEBS Lett. 313:109-112.

8. Puri, P.L., et al. 1995. Reactive oxygen intermediates mediate angiotensin II-induced c-Jun.c-Fos heterodimer DNA binding activity and proliferative hypertrophic responses in myogenic cells. J. Biol. Chem. 270:22129-22134.

9. Marrero, M.B., et al. 1995. Direct stimulation of Jak/STAT pathway by the angiotensin II AT1 receptor. Nature. 375:247-250.

10. Han, Y., Runge, M.S., and Brasier, A.R. 1999. Angiotensin II induces interleukin- 6 transcription in vascular smooth muscle cells through pleiotropic activation of nuclear factor-kappa B transcription 
factors. Circ. Res. 84:695-703.

11. Kranzhofer, R., et al. 1999. Angiotensin induces inflammatory activation of human vascular smooth muscle cells. Arterioscler. Thromb. Vasc. Biol. 19:1623-1629.

12. Pueyo, M.E., et al. 2000. Angiotensin II stimulates endothelial vascular cell adhesion molecule-1 via nuclear factor-kappaB activation induced by intracellular oxidative stress. Arterioscler. Thromb. Vasc. Biol. 20:645-651.

13. Shindo, T., et al. 2002. Kruppel-like zinc-finger transcription factor KLF5/BTEB2 is a target for angiotensin II signaling and an essential regulator of cardiovascular remodeling. Nat. Med. 8:856-863.

14. Wasylyk, B., Hahn, S.L., and Giovane, A. 1993. The Ets family of transcription factors. Eur. J. Biochem. 211:7-18.

15. Risau, W., and Flamme, I. 1995. Vasculogenesis. Annu. Rev. Cell Dev. Biol. 11:73-91.

16. Oda, N., Abe, M., and Sato, Y. 1999. ETS-1 converts endothelial cells to the angiogenic phenotype by inducing the expression of matrix metalloproteinases and integrin beta3. J. Cell. Physiol. 178:121-132.

17. Wakiya, K., Begue, A., Stehelin, D., and Shibuya, M. 1996. A cAMP response element and an Ets motif are involved in the transcriptional regulation of flt-1 tyrosine kinase (vascular endothelial growth factor receptor 1) gene. J. Biol. Chem. 271:30823-30828.

18. Hasegawa, Y., et al. 2004. Transcriptional regulation of human angiopoietin-2 by transcription factor Ets-1. Biochem. Biophys. Res. Commun. 316:52-58.

19. Elvert, G., et al. 2003. Cooperative interaction of hypoxia-inducible factor-2alpha (HIF-2alpha) and Ets-1 in the transcriptional activation of vascular endothelial growth factor receptor-2 (Flk-1). J. Biol. Chem. 278:7520-7530.

20. Nakano, T., et al. 2000. Angiogenesis inhibition by transdominant mutant Ets-1. J. Cell. Physiol. 184:255-262

21. Hultgardh-Nilsson, A., et al. 1996. Regulated expression of the ets- 1 transcription factor in vascular smooth muscle cells in vivo and in vitro. Circ. Res. 78:589-595.

22. Goetze, S., et al. 2001. TNFalpha induces expression of transcription factors c-fos, Egr-1, and Ets-1 in vascular lesions through extracellular signalregulated kinases 1/2. Atherosclerosis. 159:93-101.

23. Naito, S., et al. 1998. Ets-1 is an early response gene activated by ET-1 and PDGF-BB in vascular smooth muscle cells. Am. J. Physiol. 274:C472-C480.

24. Dzau, V.J. 2001. Theodore Cooper Lecture: tissue angiotensin and pathobiology of vascular disease: a unifying hypothesis. Hypertension. 37:1047-1052.

25. Tummala, P.E., et al. 1999. Angiotensin II induces vascular cell adhesion molecule-1 expression in rat vasculature: a potential link between the reninangiotensin system and atherosclerosis. Circulation. 100:1223-1229.

26. Gu, L., et al. 1998. Absence of monocyte chemoattractant protein-1 reduces atherosclerosis in low density lipoprotein receptor-deficient mice. Mol. Cell. 2:275-281.

27. Weiss, D., Kools, J.J., and Taylor, W.R. 2001. Angiotensin II-induced hypertension accelerates the development of atherosclerosis in apoE-deficient mice. Circulation. 103:448-454.

28. Intengan, H.D., and Schiffrin, E.L. 2001. Vascular remodeling in hypertension: roles of apoptosis, inflammation, and fibrosis [review]. Hypertension. 38:581-587.

29. Ratajska, A., Campbell, S.E., Cleutjens, J.P., and Weber, K.T. 1994. Angiotensin II and structural remodeling of coronary vessels in rats. J. Lab. Clin.
Med. 124:408-415.

30. Huggins, C.E., Domenighetti, A.A., Pedrazzini, T., Pepe, S., and Delbridge, L.M. 2003. Elevated intracardiac angiotensin II leads to cardiac hypertrophy and mechanical dysfunction in normotensive mice. J. Renin Angiotensin Aldosterone Syst. 4:186-190.

31. Higaki, J., et al. 2000. In vivo evidence of the importance of cardiac angiotensin-converting enzyme in the pathogenesis of cardiac hypertrophy. Arterioscler. Thromb. Vasc. Biol. 20:428-434.

32. Rugale, C., Delbosc, S., Cristol, J.P., Mimran, A., and Jover, B. 2003. Sodium restriction prevents cardiac hypertrophy and oxidative stress in angiotensin II hypertension. Am. J. Physiol. Heart Circ. Physiol. 284:H1744-H1750.

33. Servant, M.J., Coulombe, P., Turgeon, B., and Meloche, S. 2000. Differential regulation of p27(Kip1) expression by mitogenic and hypertrophic factors: involvement of transcriptional and posttranscriptional mechanisms. J. Cell Biol. 148:543-556

34. Rajagopalan, S., et al. 1996. Angiotensin II-mediated hypertension in the rat increases vascular superoxide production via membrane NADH/NADPH oxidase activation. Contribution to alterations of vasomotor tone. J. Clin. Invest. 97:1916-1923.

35. Zhang, C., Kavurma, M.M., Lai, A., and Khachigian, L.M. 2003. Ets-1 protects vascular smooth muscle cells from undergoing apoptosis by activating p21WAF1/Cip1: ETS-1 regulates basal and inducible p21WAF1/Cip transcription via distinct cis-acting elements in the $21 \mathrm{WAF} / \mathrm{Cip} 1$ promoter. J. Biol. Chem. 278:27903-27909.

36. Levkau, B., et al. 2001. xIAP induces cell-cycle arrest and activates nuclear factor-kappaB: new survival pathways disabled by caspase-mediated cleavage during apoptosis of human endothelial cells. Circ. Res. 88:282-290.

37. Akimaro Kudo, F., et al. 2002. Induction of apoptosis after stent implantation in canine portal vein. Ann. Vasc. Surg. 16:456-461.

38. Sato, Y., et al. 2001. Role of transcription factors in angiogenesis: Ets-1 promotes angiogenesis as well as endothelial apoptosis [review]. Ann. N. Y. Acad. Sci. 947:117-123.

39. Zhu, Y., Carmeliet, P., and Fay, W.P. 1999. Plasminogen activator inhibitor-1 is a major determinant of arterial thrombolysis resistance. Circulation. 99:3050-3055

40. Stefansson, S., and Lawrence, D.A. 1996. The serpin PAI-1 inhibits cell migration by blocking integrin alpha $V$ beta 3 binding to vitronectin. Nature. 383:441-443.

41. Heymans, S., et al. 1999. Inhibition of plasminogen activators or matrix metalloproteinases prevents cardiac rupture but impairs therapeutic angiogenesis and causes cardiac failure. Nat. Med. 5:1135-1142

42. Werb, Z., Mainardi, C.L., Vater, C.A., and Harris, E.D., Jr. 1977. Endogenous activation of latent collagenase by rheumatoid synovial cells. Evidence for a role of plasminogen activator. N. Engl. J. Med. 296:1017-1023.

43. He, C.S., et al. 1989. Tissue cooperation in a proteolytic cascade activating human interstitial collagenase. Proc. Natl. Acad. Sci. U. S. A. 86:2632-2636.

44. Olman, M.A., Mackman, N., Gladson, C.L., Moser, K.M., and Loskutoff, D.J. 1995. Changes in procoagulant and fibrinolytic gene expression during bleomycin-induced lung injury in the mouse. J. Clin. Invest. 96:1621-1630.

45. Oikawa, T., Freeman, M., Lo, W., Vaughan, D.E., and Fogo, A. 1997. Modulation of plasminogen activator inhibitor-1 in vivo: a new mechanism for the anti-fibrotic effect of renin-angiotensin inhibition. Kidney Int. 51:164-172.
46. Kaikita, K., et al. 2001. Plasminogen activator inhibitor-1 deficiency prevents hypertension and vascular fibrosis in response to long-term nitric oxide synthase inhibition. Circulation. 104:839-844.

47. Kaikita, K., et al. 2002. Potential roles of plasminogen activator system in coronary vascular remodeling induced by long-term nitric oxide synthase inhibition. J. Mol. Cell. Cardiol. 34:617-627.

48. Gerard, C., and Rollins, B.J. 2001. Chemokines and disease. Nat. Immunol. 2:108-115.

49. Ishibashi, M., et al. 2004. Critical role of monocyte chemoattractant protein-1 receptor CCR2 on monocytes in hypertension-induced vascular inflammation and remodeling. Circ. Res. 94:1203-1210.

50. Koyanagi, M., et al. 2000. Role of monocyte chemoattractant protein-1 in cardiovascular remodeling induced by chronic blockade of nitric oxide synthesis. Circulation. 102:2243-2248.

51. Bush, E., et al. 2000. CC chemokine receptor 2 is required for macrophage infiltration and vascular hypertrophy in angiotensin II-induced hypertension. Hypertension. 36:360-363.

52. Ni, W., et al. 2004. Monocyte chemoattractant protein- 1 is an essential inflammatory mediator in angiotensin II-induced progression of established atherosclerosis in hypercholesterolemic mice. Arterioscler. Thromb. Vasc. Biol. 24:534-539.

53. Ishibashi, M., et al. 2004. Bone marrow-derived monocyte chemoattractant protein-1 receptor CCR2 is critical in angiotensin II-induced acceleration of atherosclerosis and aneurysm formation in hypercholesterolemic mice. Arterioscler. Thromb. Vasc. Biol. 24:e174-e178.

54. Ueda, A., Ishigatsubo, Y., Okubo, T., and Yoshimura, T. 1997. Transcriptional regulation of the human monocyte chemoattractant protein-1 gene. Cooperation of two NF-kappaB sites and NF-kappaB/Rel subunit specificity. J. Biol. Chem. 272:31092-31099.

55. Suzuki, E., et al. 2004. Myocyte enhancer factor 2 mediates vascular inflammation via the p38-dependent pathway. Circ. Res. 95:42-49.

56. Wang, L., Fan, C., Topol, S.E., Topol, E.J., and Wang, Q. 2003. Mutation of MEF2A in an inherited disorder with features of coronary artery disease. Science. 302:1578-1581.

57. Zhan, Y., et al. 2003. Role of JNK, p38, and ERK in platelet-derived growth factor-induced vascular proliferation, migration, and gene expression. Arterioscler. Thromb. Vasc. Biol. 23:795-801.

58. Muthusamy, N., Barton, K., and Leiden, J.M. 1995. Defective activation and survival of $\mathrm{T}$ cells lacking the Ets-1 transcription factor. Nature. 377:639-642.

59. Barton, K., et al. 1998. The Ets-1 transcription factor is required for the development of natural killer cells in mice. Immunity. 9:555-563.

60. Takemoto, M., et al. 1997. Important role of tissue angiotensin-converting enzyme activity in the pathogenesis of coronary vascular and myocardial structural changes induced by long-term blockade of nitric oxide synthesis in rats. J. Clin. Invest. 99:278-287.

61. Wu, L., et al. 2002. Effect of angiotensin II type 1 receptor blockade on cardiac remodeling in angiotensin II type 2 receptor null mice. Arterioscler. Thromb. Vasc. Biol. 22:49-54.

62. Oettgen, P., et al. 1996. Characterization of NERF, a novel transcription factor related to the Ets factor ELF-1. Mol. Cell. Biol. 16:5091-5106.

63. Farr, A., and Roman, A. 1992. A pitfall of using a second plasmid to determine transfection efficiency. Nucleic Acids Res. 20:920.

64. Dube, A., Akbarali, Y., Sato, T.N., Libermann, T.A., and Oettgen, P. 1999. Role of the Ets transcription factors in the regulation of the vascular-specific Tie2 gene. Circ. Res. 84:1177-1185. 